\title{
Quantitative analysis of thyroid gland blood supply in children and adolescents
}

\section{Çocuklarda ve ergenlerde tiroid bezi kanlanmasının kantitatif analizi}

\author{
'Emine Uysal (D), 'Mehmet Öztürk (D), '2Zuhal Bayramoğlu (D), 'Hakan Cebeci (D)
}

'Selçuk University Faculty of Medicine Department of Radiology, Konya Türkiye

Istanbul Faculty of Medicine Department of Radiology, İstanbul Türkiye

\section{Correspondence}

Emine Uysal, Selcuk University Faculty of Medicine, Department of Radiology, Alaeddin Keykubat Yerleşkesi, Akadem Mah. Yeni Istanbul Street. No:369, 42030 Konya, Turkey

E-Mail: druysalemine@gmail.com

How to cite?

Uysal E, Öztürk M, Bayramoğlu Z Cebeci H. Quantitative analysis of thyroid gland blood supply in children and adolescents. Genel Tip Derg. 2022;32(1):89-94

\begin{abstract}
Aim: This study aims to determine the reference vascularization index (VI) values for the thyroid gland in healthy children and adolescents using Super microvascular imaging (SMI). It was also investigated that the correlation between thyroid vascularity and thyroid lobe volumes, age, sex, weight, height, and body mass index (BMI).

Materials and Methods: One hundred and twenty-four children and adolescents without a thyroid gland and systemic disease, and medical history affecting the thyroid gland were included in the study. Participants with abnormal thyroid function tests were excluded from the study. Age, gender, height, and weight were recorded before ultrasonography and SMI examinations. After the grayscale ultrasonography, VI values for each participant were obtained using SMI. The association between the VI and thyroid lobe volumes, age, sex, weight, height, and BMI values were analyzed.

Results: Median values of the age, height, weight, and BMI of 124 participants were 10 (6-12) years, 130 (120-152) cm, 30.5 (21-47) kg, 17.55 (15.37-21.14) kg/m2, respectively. Median (IQR) values of the left and right thyroid lobe volumes were $1.4(0.9-2.07) \mathrm{mL}$ and 1.9 (1.2-3.07) $\mathrm{mL}$, respectively, and the mean $\mathrm{VI}$ value was $5.31 \pm 1.84 \%$. There was no significant association of $\mathrm{VI}$ values with the thyroid lobe volume. Also, there was no relation between the mean VI values and the auxological parameters.

Conclusion: This study defines the VI values of thyroid glands in healthy adolescents and children. It also demonstrated no correlation between VI values of the thyroid gland and thyroid lobe volume, sex, age, weight, height, and BMI.
\end{abstract}

Key Words: adolescents, children, superb microvascular imaging, thyroid gland, ultrasonography, vascularization index

\section{Öz}

Amaç: Bu çalışma sağlıklı çocuk ve ergenlerde Süper mikrovasküler görüntüleme (SMG) kullanılarak tiroid bezi için referans vaskülarizasyon indeksi (Vi) değerlerini belirlemeyi amaçlamaktadır. Ayrıca tiroid vaskülaritesi ile tiroid lob hacimleri, yaş, cinsiyet, ağırlık, boy ve vücut kitle indeksi (VKi) arasındaki korelasyon da araştırıldı.

Gereç ve yöntem: Tiroid bezi hastalığı, sistemik hastalığı olmayan ve tiroid bezini etkileyen bir tıbbi geçmişi olmayan 124 çocuk ve ergen çalışmaya dahil edildi. Tiroid fonksiyon testleri anormal olanlar çalışma dışında bırakıldı. Katılımcıların yaşı, cinsiyeti, boyu ve kilosu ultrasonografi ve SMG tetkikleri öncesinde kaydedildi. Gri skala ultrasonografik incelemeden sonra, SMG kullanılarak her bir katıımcı için Vi değerleri elde edildi. Vi ile tiroid lob hacimleri, yaş, cinsiyet, ağırlık, boy ve VKi değerleri arasındaki ilişki analiz edildi.

Bulgular: Yüz yirmi dört katıımcının yaş, boy, kilo ve VKi ortanca değerleri sırasıyla 10 (6-12) yıl, $130(120-152) \mathrm{cm}, 30.5$ (21-47) kg, 17.55 (15.37-21.14) kg/m2 idi. Sol ve sağ tiroid lob hacimlerinin medyan (IQR) değerleri sırasıyla $1.4(0.9-2.07) \mathrm{mL}$ ve $1.9(1.2-3.07) \mathrm{mL}$ ve ortalama Vi değeri \% $5.31 \pm$ 1.84 idi. Sol ve sağ tiroid lob hacimleri ile Vi değerleri arasında anlamlı bir ilişki yoktu. Aynı zamanda, ortalama Vi değerleri ile oksolojik parametreler arasında bir ilişki saptanmadı.

Sonuç: Bu çalışma, sağlıklı ergen ve çocuklarda tiroid bezlerinin normal vi değerlerini tanımlamaktadır. Tiroid bezinin Vi değerleri ile tiroid lob hacimleri, cinsiyet, yaș, ağırlık, boy ve VKi arasında herhangi bir ilişki tespit edilmedi.

Anahtar Kelimeler: ergenler, çocuklar, superb mikrovasküler görüntüleme, tiroid bezi, ultrasonografi, vaskülarizasyon indeksi

\section{Introduction}

Ultrasonography (US) has been proven to be a morphologic evaluations of thyroid disorders (3, 4). valuable imaging method in diagnosing diffuse and Hypoechogenicity and heterogeneity of the thyroid focal lesions of the thyroid gland (1). The examinations parenchyma in grayscale US images are the most of thyroid gland volume and echogenicity of thyroid important indicators of parenchymal diseases. However, parenchyma are essential in the initial evaluation to date, those features have been general findings for and subsequent follow-up of thyroid diseases these diseases and are not helpful in the differential (2). Grayscale and Doppler US imaging are the diagnosis. Detection of increased thyroid vascularity on basic imaging modalities used in functional and the Doppler US examination is very significant for thyroid 
diseases (5). Thyroid parenchymal blood supply has been shown to increase, especially in Graves' disease and early stages of Hashimoto's thyroiditis.

Superb microvascular imaging (SMI) is an ultrasonographic imaging method that could successfully distinguish low-speed current signals from tissue motion artifacts. This feature may also display low-speed currents and small vessels, even in high resolution and in detail (6). For the motion suppression, alterations in the locations of structures are extracted out frame by frame, and only the color imaging sections are left. Compared with conventional Doppler techniques, it uses a higher frame rate, and the most prominent advantage of SMl is that it has accomplished imaging very fine vascular structures (7). SMI has two modes, color, and monochrome.

Color-coded Doppler signals accompany the grayscale US images simultaneously in color SMI mode; in comparison, monochrome mode enhances the visibility of low-current vessels by suppressing background signals. Utilizing the vascularization index (VI) parameter, SMI allows quantitative data analysis. $\mathrm{VI}$ is a ratio of colored pixels to the total of the gray and colored pixels within the area of interest, which is calculated by the automated application. Its unit is expressed as a number between 0 and $100(8,9)$.

Several studies have evaluated the difference in thyroid vascularity between children with thyroid parenchymal diseases such as Hashimoto thyroiditis and Graves' disease and the control group using SMI $(8,9,10)$. Surprisingly, until now, there has been only one study in literature, determining normative vascularity values of thyroid parenchyma in healthy children (11). The purpose of our study is to determine reference $\mathrm{VI}$ values of the thyroid gland using SMI in healthy children and adolescents. We also intended to investigate the correlation between thyroid vascularity and thyroid lobe volumes, age, sex, weight, height, and body mass index (BMI).

\section{Materials and Methods}

\section{Study design and patients}

The local ethics committee approved this prospective study (Document Date and Number: 04/07/20182018/274), and written informed parental consent was obtained before US examinations. One hundred twenty-four children and adolescents ( 62 boys and 62 girls) aged 3-17 years were evaluated from January 2019 to May 2019. The participants without a known thyroid gland and systemic disease and medical history affecting the thyroid gland were included. The exclusion criteria were abnormal ultrasonography findings of the thyroid gland and previous diagnosis with a thyroid disorder (e.g., neoplastic, infectious, autoimmune, or inflammatory). Participants with abnormal thyroid function tests were excluded from the study. Children under three years old were not included in the study since they would not stand still during the examination. Age, gender, height, and weight of the children and adolescents were noted before the US and SMI examinations. BMI was calculated using $B M I=$ weight $(\mathrm{kg}) /$ height $(\mathrm{m}) 2$. The study participants were arranged into three subgroups primarily by age as 3 to 6 years (preschool, $n=36$ ), 7 to 12 years (school age, $n=61$ ), and 13 to 17 years (adolescent, $n=27$ ). Besides, the subjects were subsequently divided into two subgroups: those over ten years old (adolescents) and those under ten years old (children). Quantitative thyroid vascularity values for each group were obtained using VI. The association of vascularity amount in the thyroid gland with thyroid lobe volumes, age, sex, weight, height, and BMI values were analyzed.

\section{US and SMI technique}

All US and SMI examinations were performed using an Aplio 500 US system (Toshiba Medical Systems, Tokyo, Japan) equipped with an 11-15-MHz linear array transducer. Examinations were carried out by a radiologist with two years of SMI experience. Subjects were examined in the supine position with the neck in mild hyperextension. Thyroid parenchyma with homogeneous echotexture without cystic or solid nodular lesions was defined as normal. Patients with heterogeneity, cystic or solid lesions of the thyroid parenchyma were not included in the study. The volume of each thyroid lobe was calculated in cubic millimeters (milliliter) using the formula "0.52 $\mathrm{x}$ width $\mathrm{x}$ length $x$ height" (Figure 1).

Figure 1. Measurement of right thyroid lobe volume from images obtained in the transverse and sagittal plane.

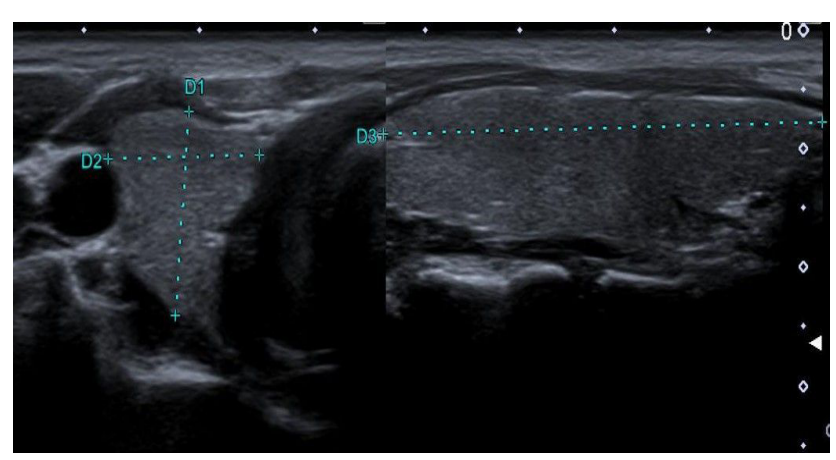

After this, the SMI software was activated. SMI investigation used a frame rate greater than $50-\mathrm{Hz}$; the pulse repetition frequency set was 220 to $234 \mathrm{~Hz}$. We used Color SMI mode and set the color gain to 30 to 40 decibels to suppress background artifacts. The participants were also asked not to swallow and to remain motionless during the examination. Durmaz et al. (9) reported no difference in the mean VI values of the thyroid gland between the axial and longitudinal plan measurements. That would mean that instead of making many measurements to achieve the average vascularity value of the thyroid gland, the mean $\mathrm{VI}$ value acquired in any plan could be used with accuracy. Therefore, in our study, we obtained thyroid 
gland VI measurements in the transverse plane. SMI analyses were carried out from the middle zone of the left and right lobes in the horizontal section. In color mode, regions of interest (ROI) in both thyroid lobes were manually outlined from the lobe boundaries, including the entire lobe. For quantitative evaluation, VI described as the ratio of colored pixels to a total of the gray and colored pixels was calculated automatically by the device (Figure 2). The mean thyroid gland $\mathrm{VI}$ value was calculated from the $\mathrm{VI}$ values obtained from the right and left thyroid lobes ([right thyroid lobe $\mathrm{VI}+$ left thyroid lobe $\mathrm{VI}] / 2$ ).

Figure 2 A, B. Color SMl of the thyroid gland. To evaluate thyroid gland vascularity, $\mathrm{VI}$ values were measured by manually drawing the bilateral thyroid lobe contours on the transverse sections.

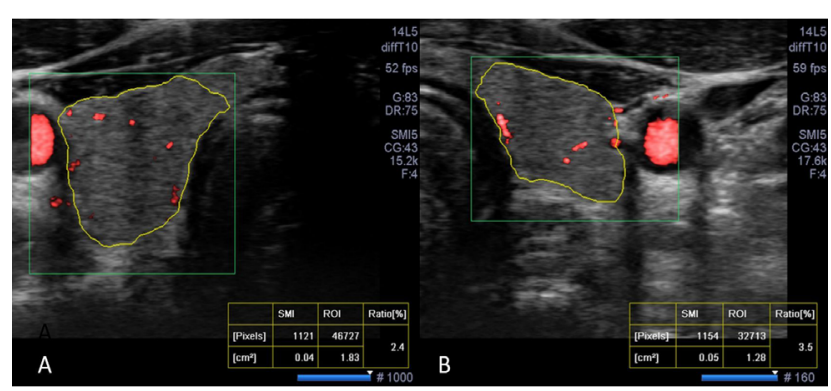

\section{Statistical analysis}

All data were recorded in Microsoft Office Excel and processed for statistical analysis using SPSS, version 21.0 (IBM Corp.). The distribution of the data was assessed with the Kolmogorov-Smirnov test. Descriptive statistics of the data were expressed as mean \pm standard deviation (SD) [minimum, maximum], or median with interquartile range (IQR). Differences in auxological parameters and thyroid lobe volume parameters among the age and gender groups were tested using the Kruskal-Wallis test or Mann-Whitney $U$ test. The Student's t-test or ANOVA test was used to compare the mean vascularity indices among the age and gender groups. Correlation analysis of the auxological, thyroid lobe volume, and VI parameters were performed using Spearman's correlation test. Variables with $\mathrm{p}$ values less than 0.05 were considered statistically significant at the $95 \%$ confidence interval. height, weight, and $\mathrm{BMI}$ ), left and right thyroid lobe volumes, and $\mathrm{VI}$ values of the participants, are given in Table 1. The median (IQR) values of the age, height, weight, and $\mathrm{BMI}$ in 124 children were 10 (6-12) years, 130 (120-152) cm, 30.5 (21-47) kg, 17.55 (15.37-21.14) $\mathrm{kg} / \mathrm{m} 2$, respectively. Median (IQR) values of the left and right thyroid lobe volumes were $1.4(0.9-2.07) \mathrm{mL}$ and $1.9(1.2-3.07) \mathrm{mL}$, respectively, and the mean $\mathrm{VI}$ value was $5.31 \pm 1.84 \%$.

The comparison of the median age, height, weight, BMI values of the participants, median left and right thyroid lobe volumes, and mean VI parameters among three age groups are given in Table 2. The median age, height, and weight values were significantly different between the three age groups and showed a remarkable increase with age $(p=0.001)$. The median $\mathrm{BMI}$ values in groups 2 and 3 were significantly higher compared to group $1(p=0.001)$. However, there was no significant difference in median BMI values between groups 2 and 3 . The median values of the right and left thyroid lobe volumes significantly differed between the three age groups and also increased with age $(p=0.001)$. In contrast, no considerable differences existed in terms of the thyroid gland mean $\mathrm{VI}$ values among these groups $(p=0.39)$.

The comparison of the median age, height, weight, BMI values of the participants, median left and right thyroid lobe volumes, and mean VI parameters among the two age groups are presented in Table 3. The medians for age, height, weight, BMl, and the left and right thyroid lobe volumes were significantly higher in group 2 compared to group $1(p=0.001)$. Besides, the mean $\mathrm{VI}$ values of the thyroid gland did not significantly differ between groups 1 and $2(p=0.53)$.

The comparison of the median age, height, weight, weight, BMI values of the participants, median left and right thyroid lobe volumes, and mean VI parameters among gender groups are given in Table 4. The medians for age, height, weight parameters, and the left and right thyroid lobe volumes were significantly higher in males compared to females $(p=0.001)$. There were no significant differences in the median $\mathrm{BMI}$ of the participants $(p=0.27)$ and mean $\mathrm{VI}(p=0.74)$ of the thyroid gland among gender groups.

\section{Results}

Descriptive statistics of auxological parameters (age,

Table 1. Descriptive statistics of auxological parameters, thyroid lobe volumes and average vascularity index in 124 children.

\begin{tabular}{|c|c|c|c|c|c|c|}
\hline & Minimum & Maksimum & Mean & Std. Dev. & Median & Interquartile range \\
\hline Age (years) & 3 & 17 & 9.55 & 3.75 & 10 & $6-12$ \\
\hline Height (cm) & 85 & 180 & 134 & 22 & 130 & $120-152$ \\
\hline Weight (kg) & 13 & 85 & 35.64 & 17.98 & 30.5 & $21-47$ \\
\hline $\mathrm{BMI}\left(\mathrm{kg} / \mathrm{m}^{2}\right)$ & 10.5 & 30.5 & 18.61 & 4.42 & 17.55 & $15.37-21.14$ \\
\hline Right lobe volume (mL) & 0.4 & 9 & 2.35 & 1.42 & 1.9 & $1.2-3.07$ \\
\hline Left Lobe volume (mL) & 0.1 & 4.6 & 1.6 & 0.94 & 1.4 & $0.9-2.07$ \\
\hline Average VI (\%) & 0.65 & 10.75 & 5.31 & 1.84 & 5.4 & $4.16-6.67$ \\
\hline
\end{tabular}


Table 2. Comparison of meantstd. Dev/median (IQR) values of auxological parameters, thyroid lobe volumes, and average vascularity index among three age groups by the ANOVA test* / Kruskal Wallis or Mann-Whitney Uf test.

\begin{tabular}{|c|c|c|c|c|}
\hline & $\begin{array}{l}\text { Age group } 1 \\
\text { (3-6 years) } \\
\text { (n:36) }\end{array}$ & $\begin{array}{l}\text { Age group } 2 \\
\text { (7-12 years) } \\
\text { (n:61) }\end{array}$ & $\begin{array}{l}\text { Age group } 3 \\
\text { (13-17 years) } \\
\text { (n:27) }\end{array}$ & p \\
\hline Age (years) & $5(4-6)$ & $10(9-11)$ & $15(13-15)$ & 0.001 \\
\hline Height $(\mathrm{cm})$ & $110(91-117)$ & $135(129-148)$ & $162(153-167)$ & 0.001 \\
\hline Weight (kg) & $18(16-21)$ & $33(25.25-47.5)$ & $50(40-60)$ & 0.001 \\
\hline BMI $\left(\mathrm{kg} / \mathrm{m}^{2}\right)$ & $15.85(14.32-17.35)$ & $18.36(15.37-22)$ & $18.55(17.12-25.76)$ & $\begin{array}{l}\text { Group } 1 \text { vs 2: } 0.001 \\
\text { Group } 2 \text { vs } 3: 0.14\end{array}$ \\
\hline Right lobe volume (mL) & $1.1(0.82-1.37)$ & $2.3(1.6-2.85)$ & $4(3-5)$ & 0.001 \\
\hline Left Lobe volume (mL) & $0.8(0.6-0.9)$ & $1.5(1.1-2)$ & $2.4(1.9-3.5)$ & 0.001 \\
\hline Average VI (\%) & $5.47 \pm 1.34$ & $5.4 \pm 2.15$ & $4.89 \pm 1.62$ & $0.39 *$ \\
\hline
\end{tabular}

Table 3. Comparison of mean \pm std. Dev/median (IQR) values of auxological parameters, thyroid lobe volumes, and average vascularity index among two age groups by the t-test* / Mann-Whitney $U$ test.

$\begin{array}{llll} & \begin{array}{l}\text { Age group 1 } \\ \text { (3-10years) } \\ \text { (n:72) }\end{array} & \begin{array}{l}\text { Age group 2 } \\ (11-17 \text { years) } \\ \text { (n:52) }\end{array} & \mathbf{0} \\ \text { Age (years) } & 7(5-9) & 13(12-15) & \mathbf{0 . 0 0 1} \\ \text { Height }(\mathrm{cm}) & 120(110-130) & 155(145-164) & \mathbf{0 . 0 0 1} \\ \text { Weight }(\mathrm{kg}) & 21.5(18-27.5) & 48(40-60.75) & \mathbf{0 . 0 0 1} \\ \text { BMl }\left(\mathrm{kg} / \mathrm{m}^{2}\right) & 15.9(14.58-18.29) & 19.29(17.3-24.91) & \mathbf{0 . 0 0 1} \\ \text { Right lobe volume }(\mathrm{mL}) & 1.5(1.02-1.97) & 3.6(2.42-4.1) & \mathbf{0 . 0 0 1} \\ \text { Left Lobe volume }(\mathrm{mL}) & 0.95(0.7-1.37) & 2.1(1.7-2.8) & \mathbf{0 . 0 0 1} \\ \text { Average VI }(\%) & 5.4 \pm 1.61 & 5.18 \pm 2.12 & 0.53^{*}\end{array}$

Table 4. Comparison of mean \pm std. Dev/median (IQR) values of auxological parameters, thyroid lobe volumes, and average vascularity index among two age groups by the t-test* / Mann-Whitney U test.

$\begin{array}{llll} & \text { Gender Groups } & & \text { P } \\ \text { Age (years) } & \text { Male (n:62) } & \text { Female (n:62) } & \mathbf{0 . 0 0 1} \\ \text { Height }(\mathrm{cm}) & 11(8.75-13) & 8(5-11) & \mathbf{0 . 0 0 1} \\ \text { Weight }(\mathrm{kg}) & 145(120-157) & 126(110-144) & \mathbf{0 . 0 0 3} \\ \text { BMl }\left(\mathrm{kg} / \mathrm{m}^{2}\right) & 36(24.75-53.25) & 25(19.75-40) & 0.27 \\ \text { Right lobe volume }(\mathrm{mL}) & 17.76(15.55-22.29) & 17.35(15.27-19.64) & \mathbf{0 . 0 0 6} \\ \text { Left Lobe volume }(\mathrm{mL}) & 2.35(1.5-3.7) & 1.8(1.1-2.75) & \mathbf{0 . 0 0 1} \\ \text { Average Vl }(\%) & 1.65(1-2.45) & 1.1(0.8-1.8) & 0.74^{*}\end{array}$

Table 5. Correlation analysis of auxological parameters with thyroid lobe volumes and average vascularity index by Spearman's correlation analysis

$\begin{array}{lcc}\text { Compared variables } & \mathbf{p} \\ \text { Age vs mean thyroid volume } & \mathbf{0 . 8 4} & \mathbf{0 . 0 0 1} \\ \text { Right lobe volume vs right lobe VI } & 0.09 \\ \text { Left lobe volume vs left lobe VI } & 0.02 \\ \text { Average VI vs age } & -0.01 & 0.98 \\ \text { Average VI vs height } & -0.11 & 0.2 \\ \text { Average VI vs weight } & -0.14 & -0.12 \\ \text { Average VI vs BMI } & 0.32\end{array}$


Table 5 presents the results of the correlation analysis. The age of the participants was significantly and strongly correlated with the left and right thyroid lobe volumes $(p=0.001, r=0.84)$. There was no relationship between the left and right thyroid lobe volumes and thyroid gland $\mathrm{VI}$ values. There were also no significant associations of the mean VI parameters with the auxological parameters.

\section{Discussion}

A significant portion of children may be affected by thyroid gland diseases such as goiter, hyperthyroidism, hypothyroidism, nodular diseases, and autoimmune thyroiditis (12). Whereas goiter and nodular diseases have rarely been observed in childhood, autoimmune thyroiditis is the most common thyroid gland disease in children and adolescents (13, 14). A multidisciplinary approach based on physical examination, blood tests, and radiological imaging techniques have been used to diagnose thyroid gland diseases (15). Although the grayscale US is the primary imaging method for investigating thyroid pathologies, US findings of the thyroid parenchyma are not sufficient to make a definitive diagnosis (16). The most frequent sonographic finding in diffuse thyroid parenchymal diseases is generally parenchymal heterogeneity and, it is non-specific and may be seen in many diseases affecting the thyroid gland.

Nevertheless, it has been reported that the investigation of thyroid parenchymal vascularity using Doppler US is beneficial in diagnosing thyroid parenchymal diseases. The diagnostic performance of color and power Doppler sonography and the influence of resistivity index detected by color Doppler US in the assessment of thyroid parenchyma have been studied in many trials $(17,18,19)$. Moreover, some studies have declared that color Doppler techniques have substantial restrictions in evaluating vascularity $(6,20,21)$. SMI remarkably reduces motion artifacts and allows the low-speed blood flow to be displayed in the capillaries $(6,19)$. Conventional Doppler techniques have also been shown to have less sensitivity for detecting abnormal vascularity in thyroid parenchymal diseases than $\operatorname{SMI}(8,9,10)$.

In a study thyroid gland VI value was reported as $4.59 \%$ for the right lobe and $4.23 \%$ for the left lobe in healthy children (11). Adaletli et al. reported the mean $\mathrm{VI}$ value of the thyroid gland in 40 healthy children as $7.3 \%$ in their study involving children with thyroid dyshormogenesis and the control group (22). A previous study of pediatric patients with Hashimoto thyroiditis, evaluating the diagnostic role of SMI and grayscale and Doppler US in thyroid pathologies, reported an average $\mathrm{VI}$ value of the thyroid gland as $7.95 \%$ in 33 healthy controls (8). In another study investigating the success of the $\mathrm{VI}$ acquired using SMI in diagnosing Hashimoto thyroiditis by Durmaz et al. (9), the thyroid gland $\mathrm{VI}$ value was stated to be $4.74 \%$ in healthy children. In the present study, too, the thyroid gland mean VI value was determined as $5.31 \pm 1.84 \%$ in
124 healthy children and adolescents. These different results in the literature may be due to differences in the number and age average of the study population, and differences occurred secondary to the measurement of the device and its user.

Previously, numerous researches conducted in children and adolescents have attempted to evaluate various organs in the head and neck region with SMI and aimed to reveal the normative $\mathrm{VI}$ values of these organs $(23,24)$. Caliskan et al. 's study $(23)$ determined normative vascularity values of the parotid gland in healthy adolescents and children using SMI, reported no correlation between vascularity values and gender, age, or BMI. In another trial evaluating the palatine tonsil vascularity by using SMl, it was demonstrated that tonsillar vascularity significantly decreased in the transition from school age to adolescence and was affected by BMl changes. The authors have suggested that tonsil vascularity does not differ by gender (24). Our study results revealed the left and right thyroid lobe volumes to be smaller in girls than in boys. There was, in contrast, no significant difference between girls and boys in the thyroid gland mean $\mathrm{VI}$ value $(5.25 \pm 1.69 \%$ in girls vs. $5.36 \pm 1.99 \%$ in boys). No significant correlation was also elicited in the current study between the thyroid gland $\mathrm{VI}$ values and thyroid lobe volumes, weight, height, and BMI. Considering that there may be changes in thyroid gland functions in different age groups and the transition from childhood to adolescence, we measured the mean values of $\mathrm{VI}$ separately for five different age groups. The vascularization index of the thyroid gland did not significantly differ, in our study, between preschool, school, and adolescent age groups. Likewise, the thyroid gland mean VI value was similar in participants under and over ten years. We could not find any relationship between thyroid gland vascularity value and age. Öztürk et al. (11), similar to our study, did not detect a correlation between thyroid gland vascularity with gender and age in children, but differently, they found a negative correlation with BMI.

SMI provides high-resolution imaging of vessels without using any contrast agents (24). It has been utilized to evaluate synovial inflammation in rheumatoid arthritis and characterize hepatic lesions and breast masses $(26,27,28,29)$. Furthermore, it is also used to evaluate thyroid nodules' preoperative evaluation (30). In current studies using SMl in the pediatric age group, $\mathrm{VI}$ values have been found to be significantly higher in patients with Hashimoto thyroiditis and Graves' disease than in healthy subjects $(8,9,10)$. In one study evaluating thyroid vascularity in the patients with Hashimoto thyroiditis and the control group, conventional doppler findings did not differ significantly between the patients in the early stage of thyroiditis and the control group. At the same time, the $\mathrm{VI}$ values obtained using SMI were significantly higher in those in the early stage of thyroiditis compared to the control group (8). This finding suggested that SMI is useful to diagnose also patients with thyroiditis who are in the 
early stages of the disease. The normative VI values of the thyroid gland found in our study for children and adolescents may be beneficial in diagnosing thyroid parenchymal diseases.

The present study has some limitations. Firstly, the study cohort included a limited number of participants. It would be useful to perform large-scale studies in children and adolescents to correctly determine the thyroid gland's normative vascularity values. Secondly, since the study was prospective, VI measurement was performed from the localization with the best blood supply during the examination. The third limitation was that children under three years old were not included in the study. Finally, since VI measurements were made by a single radiologist, the interobserver agreement could not be evaluated.

In conclusion, our study defines the normative VI values of thyroid glands in healthy adolescents and children. Remarkably, no correlation between the thyroid gland $\mathrm{VI}$ values and thyroid lobe volumes, sex, age, weight, height, and BMI were demonstrated. These data may be helpful for the design of further studies regarding thyroid parenchyma diseases. In addition, it would be beneficial to use SMl, which is a valuable imaging method in addition to grayscale US, and to compare the obtained $\mathrm{VI}$ values with normative values in the diagnosis of thyroid gland diseases in children.

\section{References}

1.Kim SJ, Kim EK, Park CS, et al. Ultrasound guided fine-needle aspiration biopsy in nonpalpable thyroid nodules: is it useful in infracentimetric nodules? Yonsei Med J 2003;44:635-40.

2.Taş F, Bulut S, Eğilmez $\mathrm{H}$, et al. Normal thyroid volume by ultrasonography in healthy children. Ann Trop Paediatr 2002;22:375-9.

3.Wu CC, Torng JK. Duplex Doppler ultrasonography for the functional evaluation of diffuse thyroid diseases. J Med Ultrasound 2009;17:183-6.

4.Erdogan MF, Anil C, Cesur M, Baskal N, Erdogan G. Color flow Doppler sonography for the etiologic diagnosis of hyperthyroidism. Thyroid 2007;1 7:223-8.

5.dos Santos TARR, Pina ROG, Souza MTP, Chammas MC. Graves' disease thyroid color-flow Doppler ultrasonography assessment: review article. Health 2014;6: 1487.

6.Jiro $H$. Seeing the unseen new techniques in vascular imaging Superb Microvascular Imaging. Toshiba Med Rev 2014.

7.Zhan J, Diao XH, Jin JM, Chen L, Chen Y. Superb Microvascular Imaging-a new vascular detecting ultrasonographic technique for avascular breast masses: a preliminary study. Eur J Radiol 2016:85:91521

8.Bayramoglu Z, Kandemirli SG, Caliskan E, et al. Assessment of paediatric Hashimoto's thyroiditis using superb microvascular imaging. Clin Radiol 2018;73:1059.e9-15.

9.Durmaz MS, Akyürek N, Kara T, et al. Quantitative assessment of thyroid gland vascularization with vascularization index using colo superb microvascular imaging in pediatric patients with hashimoto thyroiditis. Ultrasound quarterly 2019;35:281-9.

10.Bayramoglu Z, Kandemirli SG, Akyol Sarı ZN, et al. Superb Microvascular Imaging in the Evaluation of Pediatric Graves Disease and Hashimoto Thyroiditis. J Ultrasound Med 2019:9999:1-9

11.Ozturk M, Durmaz MS, Ateş F, et al. Assessment of thyroid gland vascularity with superb microvascular imaging in healthy children and its relationship with potential factors. J Pediatr Endocrinol Metab 2020;33:1 139-45.

12.Rallison ML, Dobyns BM, Meikle AW, et al. Natural history of thyroid abnormalities: prevalence, incidence, and regression of thyroid diseases in adolescents and young adults. Am J Med 1991;91:363-70.

13.Brown RS. Autoimmune thyroiditis in childhood. J Clin Res Pediatr Endocrinol 2013;1:45-9.

14.Brix TH, Hegedüs L. Twin studies as a model for exploring the etiology of autoimmune thyroid disease. Clin Endocrinol (Oxf) 2012;76:457-64.

15.Corrias A, Mussa A, Baronio F, et al. Diagnostic features of thyroid nodules in pediatrics. Arch Pediatr Adolesc Med 2010;164:714-9.

16. Moon HJ, Sung JM, Kim EK, et al. Diagnostic performance of grayscale US and elastography in solid thyroid nodules. Radiology 2012;262:1002-13.

17. Banaka I, Thomas D, Kaltsas G. Value of the left inferior thyroid artery peak systolic velocity in diagnosing autoimmune thyroid disease. J Ultrasound Med 2013;32:1969-78.

18.Acar T, Ozbek SS, Erdogan M, Özgen AG, Demirel SO. US findings in euthyroid patients with positive antithyroid autoantibody tests compared to normal and hypothyroid cases. Diagn Interv Radio 2013;19:265-70.

19.Sarikaya B, Demirbilek H, Akata D, Kandemir N. The role of the resistive index in Hashimoto's thyroiditis: a sonographic pilot study in children. Clinics (Sao Paulo, Brazil) 2012;67:1253-7.

20. Machado $P$, Forsberg F. Initial experience with a novel microvascular flow imaging technique. Toshiba Med Rev 2014.

21.Arslan S, Karahan AY, Oncu F, et al. Diagnostic performance of superb microvascular imaging and other sonographic modalities in the assessment of lateral epicondylosis. J Ultrasound Med 2018;37:58593

22.Adaletli I, Bayramoglu Z, Caliskan E, et al. Multi-parametric Ultrasound Evaluation of Pediatric Thyroid Dyshormonogenesis. Ultrasound Med Biol 2019;45:1644-53.

23.Caliskan E, Ozturk M, Bayramoglu Z, Comert RG, Adaletli I. Evaluation of parotid glands in healthy children and adolescents using shear wave elastography and superb microvascular imaging. La radiologia medica 2018;123:710-8.

24.Caliskan E, Ozturk M, Bayramoglu Z, Adaletli I. Superb Microvascular Imaging of Palatine Tonsils in Healthy Children: A Preliminary Study. Ultrasound Q. 2018:34:71-6.

25. Goddi A, Fanizza M, Bortolotto C. Vector flow imaging techniques: an innovative ultrasonographic technique for the study of blood flow. $\mathrm{J}$ Clin Ultrasound 2017;45:582-8.

26. Orlandi D, Gitto S, Perugin Bernardi S, et al. Advanced power Doppler technique increases synovial vascularity detection in patients with rheumatoid arthritis. Ultrasound Med Biol 2017;43:1880-87.

27.Yokota K, Tsuzuki Wada T, Akiyama Y, Mimura T. Detection of synovial inflammation in rheumatic diseases using Superb Microvascular Imaging: comparison with conventional power Doppler imaging. Mod Rheumatol 2018;28:327-33.

28.Park AY, Seo BK, Woo OH, et al. The utility of ultrasound Superb Microvascular Imaging for evaluation of breast tumour vascularity: comparison with colour and power Doppler imaging regarding diagnostic performance. Clin Radiol 2018;73:304-11.

29.Lee DH, Lee JY, Han JK. Superb Microvascular Imaging technology for ultrasound examinations: initial experiences for hepatic tumors. Eur J Radiol 2016:85:2090-5.

30.Kong J, Li JC, Wang HY, et al. Role of superb microvascular imaging in the preoperative evaluation of thyroid nodules: comparison with power Doppler flow imaging. J Ultrasound Med 2017;36:1329-37 